\title{
EVALUATION OF PROXIMATE COMPOSITION OF FRUITS OF Lycopersicon esculentum (Roma VF) UNDER STRESS AND STAKING
}

\section{S.E. OSIM, C. S. ODOEMENA, M.M. ETUKUDO, K. OKONWU, AND P. EREMRENA,}

(Received 22 March 2010; Revision Accepted 21, June 2010)

\begin{abstract}
The effects of salt $\left(\mathrm{CaCl}_{2}\right)$ and staking on the proximate composition of fruits of tomato (Roma VF) were studied at the Department of Botany Experimental garden, University of Uyo, Nigeria. Calcium chloride salt levels of 0 , $50,100,150$ and $200 \mathrm{~g}$ per $4 \mathrm{Kg}$ of loamy sandy soil were used, with and without staking. The moisture, dry matter, ash, crude fat, crude protein, carbohydrate and crude fibre contents in treatment with calcium chloride/ staking were significantly $(\mathrm{P}<0.05)$ higher than those of calcium chloride without staking in Roma VF. $\mathrm{CaCl}_{2}$ and staking treatment increased the crude protein content of the crop. $100 \mathrm{~g} \mathrm{level} \mathrm{of} \mathrm{CaCl}_{2}$ salt was the optimum level for enhanced proximate composition of the crop. Improved processing qualities of tomato fruit (Roma VF) can be enhanced through regulated salt and staking treatment.
\end{abstract}

KEY WORDS: Proximate composition, salt stress, staking and Lycopersicon esculentum

\section{INTRODUCTION}

Tomato (Lycopersicon esculentum Mill) belongs to the family Solanaceae, and is grown mainly for its fruits, in view of its dietary importance (Bertin, 2005). Agronomic management requirement and salt tolerance level affect plant growth and development (Schippers, 2000; Odoemena, 2006). The physiological reaction of salts is one of the major factors determining the uptake of nutrients by plants (Munns et al., 2001) hence may affect the nutritional values and essential biochemical attributes for processing. Salt stress differ considerably from one plant to another, and the variation in tolerance results in differential growth response of crops to saline medium (Rengasamy, 2006; Munns et al., 2001). Therefore, this study was aimed at evaluating the response of Tomato (Roma VF) to salt stress and agronomic management requirement of staking.

\section{MATERIALS AND METHODS}

Seeds of the tomato cultivar (Roma VF) obtained from Horticultural Research Institute Okigwe Seed Bank were sown in a nursery consisting of a perforated wooden box $(45 \times 60 \mathrm{~cm})$ filled with loamy sandy soil mixed with poultry droppings for germination in June, 2003. Seedlings were transplanted after 4 weeks to the experimental site. The experimental treatments consisted of 0 (control), 50, 100, 150 and $200 \mathrm{~g}$ of calcium chloride $\left(\mathrm{CaCl}_{2}\right)$ with and without staking. Four kilograms of loamy - sandy soil $(0-45 \mathrm{~cm}$ depth) obtained from the fallow land within University of Uyo Botanic and Horticultural farm, Akwa Ibom State were weighed and thoroughly mixed with poultry droppings, in the proportion of two parts of soil to one part of poultry manure (Odoemena, 2006). It was left for 7 days before transferring the seedlings into perforated polythene bags $(18 \times 36 \mathrm{~cm})$. Uniform and healthy seedlings of the cultivar were differently transplanted into each of the prepared perforated polythene bags (1 seedling per poly bag) containing the poultry manured soil. Staking was done 2 weeks after transplanting as part of the treatment except for those of the control treatment. Calcium chloride treatment, which commenced 18 days after transplanting and lasted for 5 weeks, was done by dissolving each treatment amount in 1 litre of distilled water (Francoise et al,, 1984). The entire experiment was repeated two times. Each level of treatment was replicated 4 times and arranged in a randomized complete block designed. The experimental work was maintained under natural light condition, the plants watered as need arose, and sprayed weekly with Dithane - M45 (Dithio - Carbonates fungicide) and Vetox 85 at the rate of $30 \mathrm{~g}$ to 9 litres of water (Agale et al., 1999). The plants were allowed to grow for 79 days (after transplanting) in order to determine the growth and yield components. Data were subjected to analysis of variance according to the method of Obi (2002)

\section{RESULTS}

The moisture, dry matter, ash, crude fat, crude protein, carbohydrate and crude fibre contents in treatment with calcium chloride / staking were significantly $(P<0.05)$ higher than those of calcium chloride without staking (Table 1 and 2). Treatment levels with low concentration of $\mathrm{CaCl}_{2}$ salt (50 and $100 \mathrm{~g}$ ) gave significant $(\mathrm{P}<0.05)$ increase in proximate compositions of Roma VF over that of the control. $100 \mathrm{~g}$ level of $\mathrm{CaCl}_{2}$ salt was the optimum level for enhanced proximate composition of the crop (Table 1 and 2). The crude fat, dry matter and crude protein contents of the crop also increased with increase in the $\mathrm{CaCl}_{2}$ salt level for the two treatments (with or without staking) (Table 1 and 2). $\mathrm{CaCl}_{2}$ salt with staking treatment effect

\section{S.E Osim, Department of Biological Sciences, Cross Rivers University of Technology, Calabar - Nigeria.}

C. S Odoemena, Department of Botany and Environmental Studies, University of Uyo, Akwa Ibom State, Nigeria

M.M., Etukudo, Department of Plant Science and Biotechnology, University of Port Harcourt, Rivers State - Nigeria.

K. Okonwu, Department of Plant Science and Biotechnology, University of Port Harcourt, Rivers State - Nigeria.

P. Eremrena, Department of Plant Science and Biotechnology, University of Port Harcourt, Rivers State -Nigeria. 
decreased the moisture, ash and carbohydrate contents of Roma VF, at 150 and $200 \mathrm{~g}$ treatment level, while $200 \mathrm{~g}$ treatment level of $\mathrm{CaCl}_{2}$ salt with staking decreased the crude fibre content of the crop, compared with the control $(0)$ treatment (Table 1$)$. In addition, there were reductions in moisture, ash, carbohydrate and crude fibre contents of the crop at higher $\mathrm{CaCl}_{2}$ salt levels without staking compared with the control (Table 2).

TABLE 1: Effect of Calcium Chloride / Staking on Proximate Composition of Tomato (Roma VF)

\begin{tabular}{|l|l|l|l|l|l|l|l|}
\hline $\begin{array}{l}\text { Treatment: } \\
\mathrm{CaCl}_{2}(\mathrm{~g}) / \\
\text { Staking }\end{array}$ & $\begin{array}{l}\text { Moisture } \\
\text { content } \\
(\%)\end{array}$ & $\begin{array}{l}\text { Dry matter } \\
(\%)\end{array}$ & $\begin{array}{l}\text { Ash } \\
\text { content } \\
(\%)\end{array}$ & $\begin{array}{l}\text { Crude fat } \\
(\%)\end{array}$ & $\begin{array}{l}\text { Crude } \\
\text { protein (\%) }\end{array}$ & $\begin{array}{l}\text { Carbohydrate } \\
(\%)\end{array}$ & $\begin{array}{l}\text { Crude } \\
\text { fibre }(\%)\end{array}$ \\
\hline 0 & $84.85 \pm 0.95$ & $8.15 \pm 0.14$ & $11.00 \pm 0.20$ & $16.05 \pm 0.30$ & $18.90 \pm 0.16$ & $41.64 \pm 0.52$ & $7.30 \pm 0.15$ \\
\hline 50 & $89.74 \pm 0.75$ & $14.26 \pm 0.15$ & $10.00 \pm 0.16$ & $16.74 \pm 0.41$ & $20.39 \pm 0.15$ & $43.27 \pm 0.30$ & $8.18 \pm 0.12$ \\
\hline 100 & $95.76 \pm 0.59$ & $16.24 \pm 0.13$ & $14.50 \pm 0.32$ & $23.38 \pm 0.14$ & $25.61 \pm 0.20$ & $59.51 \pm 0.16$ & $8.49 \pm 0.16$ \\
\hline 150 & $83.70 \pm 0.79$ & $17.32 \pm 0.10$ & $9.50 \pm 0.13$ & $27.91 \pm 0.31$ & $32.23 \pm 0.34$ & $37.35 \pm 0.31$ & $8.07 \pm 0.12$ \\
\hline 200 & $75.10 \pm 0.51$ & $19.90 \pm 0.12$ & $7.50 \pm 0.26$ & $28.38 \pm 0.20$ & $34.37 \pm 0.14$ & $34.53 \pm 0.46$ & $6.20 \pm 0.30$ \\
\hline
\end{tabular}

Mean \pm Standard error $(P<0.05)$

TABLE 2: Effect of Calcium Chloride / Staking on Proximate Composition of Tomato (Roma VF)

\begin{tabular}{|l|l|l|l|l|l|l|l|}
\hline $\begin{array}{l}\text { Treatment: } \\
\begin{array}{l}\mathrm{CaCl}_{2}(\mathrm{~g}) / \\
\text { without } \\
\text { Staking }\end{array}\end{array}$ & $\begin{array}{l}\text { Moisture } \\
\text { content } \\
(\%)\end{array}$ & $\begin{array}{l}\text { Dry matter } \\
(\%)\end{array}$ & $\begin{array}{l}\text { Ash } \\
\text { content } \\
(\%)\end{array}$ & $\begin{array}{l}\text { Crude fat } \\
(\%)\end{array}$ & $\begin{array}{l}\text { Crude } \\
\text { protein (\%) }\end{array}$ & $\begin{array}{l}\text { Carbohydrate } \\
(\%)\end{array}$ & $\begin{array}{l}\text { Crude } \\
\text { fibre (\%) }\end{array}$ \\
\hline 0 & $73.26 \pm 0.39$ & $6.21 \pm 0.31$ & $9.00 \pm 0.43$ & $12.32 \pm 0.17$ & $15.30 \pm 0.24$ & $32.40 \pm 0.19$ & $5.32 \pm 0.09$ \\
\hline 50 & $80.25 \pm 0.52$ & $12.32 \pm 0.26$ & $8.50 \pm 0.40$ & $14.70 \pm 0.32$ & $17.32 \pm 0.30$ & $34.16 \pm 0.10$ & $6.10 \pm 0.48$ \\
\hline 100 & $77.46 \pm 0.67$ & $13.20 \pm 0.17$ & $12.50 \pm 0.19$ & $18.31 \pm 0.19$ & $20.40 \pm 0.46$ & $47.32 \pm 0.22$ & $7.64 \pm 0.42$ \\
\hline 150 & $63.46 \pm 0.28$ & $14.02 \pm 0.14$ & $8.10 \pm 0.30$ & $20.21 \pm 0.31$ & $24.52 \pm 0.17$ & $28.67 \pm 0.15$ & $5.02 \pm 0.22$ \\
\hline 200 & $62.25 \pm 0.46$ & $16.22 \pm 0.21$ & $6.10 \pm 0.16$ & $21.20 \pm 0.22$ & $29.20 \pm 0.23$ & $26.12 \pm 0.20$ & $4.27 \pm 0.40$ \\
\hline
\end{tabular}

Mean \pm Standard error $(P<0.05)$

\section{DISCUSSION}

The disparities evident between $\mathrm{CaCl}_{2}$ salt / staking and $\mathrm{CaCl}_{2}$ salt without staking treatments in proximate composition of Roma VF can be attributed to variation in the agronomic practice used for the two treatments. This result agrees with the work of Agbede (2009), who reported that, the nutrient composition of plant materials vary with the age, cultural practices, environment, the season and the varieties. Staking is an agronomic management requirement for enhanced plant development, particularly in erect types cultivars that requires external support (Udo et al., 2005).

The decrease in moisture contents with increasing levels of $\mathrm{CaCl}_{2}$ salt in Roma VF was evident for both staking and non-staking treatments against the increased dry matter contents of the crop. This result agrees with the reports of Nobson and Grierson (1993), that under an increased salt content of the soil, water rather than dry matter accumulation by the fruit was affected.

The crude protein content of Roma VF increased with $\mathrm{CaCl}_{2}$ salt application. Increase in protein content observed in this study agrees with the findings of Cusido et al.,(1987), and Gupta and Gupta, (2005) who reported that high salt application increase protein synthesis. Accumulation of certain protein in response to salt stress have been reported, although salt induced changes in proteins have been shown to be species specific (Flowers and Dalmond, 1992; Fricke, 2004).

\section{CONCLUSION}

This study shows that a regulated agronomic management practice and salt application can be employed to improve the processing qualities of tomatoes (Roma VF) fruit. Thus, a local cultivar of tomato such as Roma VF which is adapted to the
Nigerian environment could be enhanced in terms of proximate composition of its fruit using a regulated salt application.

\section{REFERENCES}

Agale, S.O., Inemiren, G.O. and Ojeniyi, S.O., 1999. Effects of plant density and mulching on the performance of late-season tomato (Lycopersicon esculentum) in Southern Nigeria. Journ. of Agric. Science, 133:397-402.

Agbede, O.O., 2009. Understanding soil and plant nutrition. Nigeria Salman Press and Co. Nig. Ltd.

Bertin, N., 2005. Analysis of the tomato fruit growth response in relation to temperature and plant fruit load, cell division, cell expansion and DNA Endoreduplication. Annals of Botany, 95(3): 439-447.

Cusido, R.M., Palazon, J., Altabella, T. and Morales, C., 1987. Effect of salinity on soluble protein, free amino acids and nicotine contents in Nicotiana rustica L., Plant and Soil, 102: 55-60.

Hobson, G. and Grierson, D., 1993. Tomato. In: Biochemistry of fruit Ripening, (Editors; G.B. Seymor, T.E. Taylor and G.A. Tucker) Chapman and Hall, London, P. 404-442. 
Flowers, T.J. and Dalmond, D., 1992. Protein synthesis in halophytes: the influence of potassium,sodium and magnesium in vitro. Plant and Soil, 146: 153-161.

Francoise, L. E., Donovan, T. and Mass, E. V., 1984. Salinity effects on seed yield, growth and germination of grain Sorghum. An American Society of Agronomy publication. Agronomy Journ., 75(5): 741-744.

Fricker, N., 2004. Rapid and Tissue-specific accumulation of solutes in the growth zone of barley leaves in response to salinity. Planta, 219: 515-525.

Gupta, N.K. and Gupta, S., 2005. Plant physiology. New Delhi Oxford IBA publishing Co. pvt. Ltd.

Munns, R., James, R.A. and Lauchli, A., 2001. Approaches to increasing the salt tolerance of wheat and other cereals. Journal of experimental Botany, 57 (5): 1025-1043.

Obi, I.U., 2002. Statistical methods of detecting differences between treatment means and research methodology Issues in Laboratory and Field experiments. Nigeria, Ap Express publishers Limited.

Odoemena, C. S. I., 2006. Effect of poultry manure on growth, yield and chemical composition of tomato (Lycopersicon esculentum Mill) cultivars. International Journal of Natural and Applied Sciences. 1(1): 51-55

Schippers, R. R., 2000. African indigenous vegetables: An overview of cultivated species. Chatlam U.K. Natural Resources Institute/ACP-EU. Technical centre for Agricultural and Rural Co-operation.

Rengasamy, P., 2006. World salinization with emphasis on Australia. Journal of experiemental Botany, 57(5): 1017-1023.

Udoh, D.J., Ndon, B.A., Asuquo. P.E., and Ndaeyo, N.U. (2005). Crop production Techniques for the Tropics. Nigeria concept publications Limited. 
